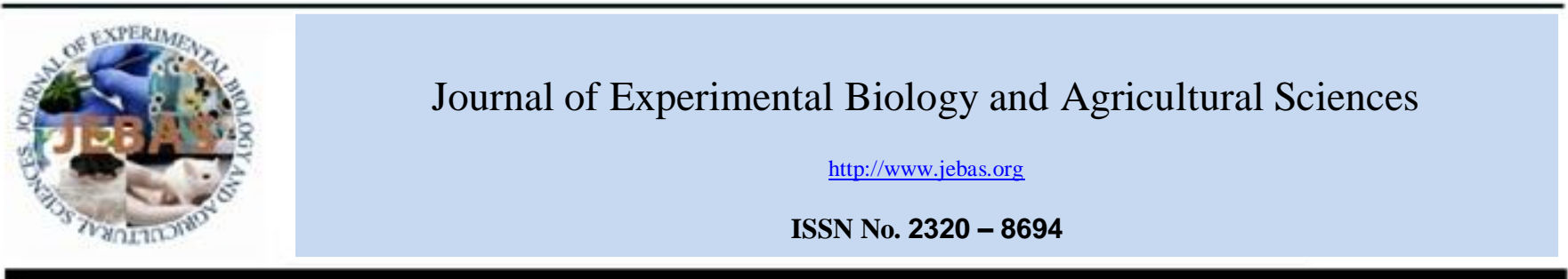

\title{
GENETIC DIVERSITY IN TRADITIONAL GENOTYPES FOR GRAIN IRON, ZINC AND $\beta$-CAROTENE CONTENTS REVEAL POTENTIAL FOR BREEDING MICRONUTRIENT DENSE RICE
}

\author{
Qasim Raza $^{1 *}$, Hira Saher ${ }^{1}$, Fariha Shahzadi $^{1}$, Awais Riaz $^{1}$, Tahira Bibi ${ }^{1}$, Muhammad Sabar $^{1}$ \\ ${ }^{1}$ Rice Research Institute, Kala Shah Kaku-39020, Sheikhupura, Pakistan.
}

Received - February 18, 2019; Revision - March 26, 2019; Accepted - April 03, 2019

Available Online - April 10, 2019

DOI: http://dx.doi.org/10.18006/2019.7(2).194.203

KEYWORDS
Bio-fortification
Genetic variability
Germplasm screening
Micronutrients
Oryza sativa
Vitamins

\begin{abstract}
Rice is the staple food for half of the world's population, however, its edible grain part is deficient in essential micronutrients, especially $\mathrm{Fe}$ and $\mathrm{Zn}$. Breeding for micronutrient dense rice demands exploration of available genetic diversity for grain $\mathrm{Fe}, \mathrm{Zn}$ and $\beta$-carotene contents. In this study, we analysed brown and polished grain samples of 26 traditional rice genotypes for $\mathrm{Fe}$ and $\mathrm{Zn}$ concentration. Fe concentration varied from $13.23 \mathrm{ppm}$ to $45.83 \mathrm{ppm}$ and $1.10 \mathrm{ppm}$ to $36.45 \mathrm{ppm}$ in brown and polished rice, respectively. Whereas, $\mathrm{Zn}$ concentration in brown and polished rice ranged from 18.67 $\mathrm{ppm}$ to $38.01 \mathrm{ppm}$ and $5.86 \mathrm{ppm}$ to $23.88 \mathrm{ppm}$, respectively. The landraces had higher $\mathrm{Fe}$ and $\mathrm{Zn}$ contents than improved varieties and advance uniform lines. Significant positive correlation was present between $\mathrm{Fe}$ and $\mathrm{Zn}$ concentration in brown $(\mathrm{r}=0.694, \mathrm{P}<0.01)$ and polished rice $(\mathrm{r}=0.533, \mathrm{P}<0.01)$. Fe concentration was greatly reduced by the polishing process than $\mathrm{Zn}$ concentration and approved varieties lost less $\mathrm{Fe}$ and $\mathrm{Zn}$ contents than advance uniform lines. Minimal levels of beta-carotene were detected in rice genotypes indicating need for genetic modifications to enhance pro-vitamin A contents in rice endosperm.
\end{abstract}

* Corresponding author

E-mail: qasimnazami@gmail.com (Qasim Raza)

Peer review under responsibility of Journal of Experimental Biology and Agricultural Sciences.

Production and Hosting by Horizon Publisher India [HPI] (http://www.horizonpublisherindia.in/).

All rights reserved.
All the article published by Journal of Experimental Biology and Agricultural Sciences is licensed under a Creative Commons Attribution-NonCommercial 4.0 International License Based on a work at www.jebas.org.

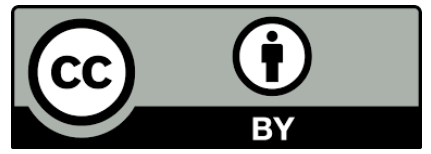




\section{Introduction}

Malnutrition or 'Hidden hunger' affects at least 2 billion peoples worldwide and $45 \%$ of deaths among children under 5 years of age are linked to under nutrition (McGuire et al., 2015; WHO, 2015). In developing countries, micronutrient malnutrition, particularly iron $(\mathrm{Fe})$ and zinc $(\mathrm{Zn})$ deficiency, is a continuing public health issue. Global studies estimated that more than $30 \%$ of the world's population is anemic due to iron-deficiency anemia (IDA) (Brotanek et al., 2005; Stevens et al., 2013). IDA affects productivity of women's along with other severe health problems, including mental retardation, weakened immune system and increased morbidity and mortality rates (Black, 2003). Zinc deficiency is a major cause of stunted growth, male hypogonadism, abnormal neurosensory changes and impaired immune function (Maret \& Sandstead, 2006). Vitamin A deficiency (VAD) is also a major health concern and causes xeropthalmia and night blindness (WHO, 2009).

In past, supplementation and fortification of food items have been practiced, however, these interventions have not been able to eradicate the problem, mainly due to the fact that these are not economically sustainable (Meenakshi et al., 2010). For instance, vitamin A supplementation programs in 103 priority countries has stagnated at $58 \%$ success rate in ten years, with high year to year fluctuation (Dalmiya \& Palmer, 2007). Among different approaches to mitigate malnutrition, biofortification is the most cost effective and sustainable intervention. It is a process of bolstering the nutritional value of edible parts of crop plants through agronomic, breeding and transgenic techniques.

Rice (Oryza sativa L.) is one of the widely grown and most consumed crops worldwide. Half of the world's population depend on it to meet their daily calorie requirements (Meng et al., 2005). However, its edible grain part (endosperm) contains insufficient levels of $\mathrm{Fe}, \mathrm{Zn}$ and $\beta$-carotene (pro-vitamin A) to meet the dietary requirements. Therefore, biofortified rice with enriched levels of essential nutrients can significantly improve global human health. In order to provide $30 \%, 40 \%$ and $50 \%$ of the dietary estimated average requirements (EAR), the polished rice should contain $15 \mathrm{ppm}$ of Fe, $28 \mathrm{ppm}$ of $\mathrm{Zn}$ and $17 \mathrm{ppm}$ of $\beta$ carotene (Bouis et al., 2011). Exploration of available genetic diversity for $\mathrm{Fe}, \mathrm{Zn}$ and $\beta$-carotene in economically important parts of the crop plants is a first step towards developing the nutrient dense crops (Bouis \& Saltzman, 2017).

Germplasm has been screened for grain $\mathrm{Fe}, \mathrm{Zn}$ and $\beta$-carotene contents in many crops, including rice. Cai et al. (2009) evaluated 113 rice landraces, including japonica and indica accessions. The variation in Fe ranged from $8.1 \mathrm{ppm}$ to $19.9 \mathrm{ppm}$ and japonica rice contained significantly higher $\mathrm{Fe}$ contents than indica rice. Banerjee et al. (2010) assessed genetic diversity in cultivated and wild accessions of rice and found wide genetic variation in grain
$\mathrm{Fe}, \mathrm{Zn}$ and protein levels. Fe contents varied from 4.82 - 22.69 ppm and $\mathrm{Zn}$ contents varied from 13.95 - 41.73 ppm, respectively. They also found high micronutrient densities in wild accessions of rice. Anandan et al. (2011) found wide genetic variability in traditional and improved rice genotypes and reported that Fe and $\mathrm{Zn}$ contents were higher in traditional genotypes than improved cultivars. Brar et al. (2011) assessed genetic diversity in a collection of 220 rice genotypes. The $\mathrm{Fe}$ and $\mathrm{Zn}$ contents in brown rice varied significantly from $5.1-441.5 \mathrm{ppm}$ and $2.12-39.4$ ppm, respectively. Anuradha et al. (2012) analysed Fe and Zn concentration in brown rice of 126 accessions and reported that wild accession had highest concentration levels. In wheat, genetic variability for grain $\mathrm{Fe}, \mathrm{Zn}$ and $\beta$-carotene contents had also been assessed by Badakhshan et al. (2013). Based on two year's data, concentration of $\mathrm{Fe}, \mathrm{Zn}$ and $\beta$-carotene ranged from 41.36 to $67.67,36.37$ to 73.80 and 0.96 to $1.69 \mathrm{ppm}$, respectively. Roy \& Sharma (2014) evaluated 84 rice accessions and concentration of Fe ranged from 0.25 - $34.8 \mathrm{ppm}$ and $\mathrm{Zn}$ ranged from 0.85 - 195.3 ppm. Patil et al. (2015) screened 60 rice genotypes and found that $\mathrm{Fe} \& \mathrm{Zn}$ contents in brown rice ranged from 3.38 - $36.99 \mathrm{ppm}$ and 3.32 - 42.49 ppm, respectively. Umadevi et al. (2016) assessed genetic variability in 57 rice genotypes for $\mathrm{Fe}$ and $\mathrm{Zn}$ contents in brown rice. The $\mathrm{Fe}$ and $\mathrm{Zn}$ concentration varied from $7.45-29.85$ ppm and 14.68 - 59.65 ppm, respectively.

Genetic diversity in local rice germplasm of Pakistan for micronutrients and vitamins has not been assessed previously. Therefore, we decided to explore it in approved varieties and advance uniform lines for fast track development of nutrient dense rice cultivars. The objectives of this study were to explore genetic diversity in traditional rice genotypes for $\mathrm{Fe}$ and $\mathrm{Zn}$ contents in brown and polished rice, as well as $\beta$-carotene levels in polished rice; analyse association between $\mathrm{Fe}$ and $\mathrm{Zn}$ concentration in brown and polished rice; examine losses in $\mathrm{Fe}$ and $\mathrm{Zn}$ contents during polishing process and identify $\mathrm{Fe}$ and $\mathrm{Zn}$ donor parents for their exploitation in nutrition breeding program.

\section{Material \& Methods}

\subsection{Experimental site, plant material and growth conditions}

Present study was conducted at the Rice Research Institute, Kala Shah Kaku (RRI, KSK), Pakistan. Twenty-six (26) rice genotypes including twelve (12) approved varieties and fourteen (14) advance uniform lines were used in this study and are listed in Table 1. During Kharif season 2017, all genotypes were grown in the experimental field of RRI, KSK under normal field conditions and seed harvested from this trial was used for further analysis. NPK and Zn fertilizers were applied at rates of 116:87:62 and 12 $\mathrm{kg} / \mathrm{ha}$, respectively. Standard agronomic and plant protection practices were followed. Soil and water samples were also collected and analysed for determination of physiochemical characteristics (Table 2). 
Table 1 List of genotypes*

\begin{tabular}{|c|c|c|c|}
\hline Sr. No. & Genotype & Status with release year & Type \\
\hline 1 & Basmati 370 & Approved Variety-1933 & Aromatic \\
\hline 2 & Basmati 198 & Approved Variety-1972 & Aromatic \\
\hline 3 & Basmati Pak & Approved Variety-1968 & Aromatic \\
\hline 4 & Basmati 385 & Approved Variety-1985 & Aromatic \\
\hline 5 & Super Basmati & Approved Variety-1996 & Aromatic \\
\hline 6 & Basmati 2000 & Approved Variety-2000 & Aromatic \\
\hline 7 & Basmati 515 & Approved Variety-2011 & Aromatic \\
\hline 8 & PK 386 & Approved Variety-2013 & Non- Aromatic \\
\hline 9 & PK 1121 Aromatic & Approved Variety-2013 & Aromatic \\
\hline 10 & Kissan Basmati & Approved Variety-2016 & Aromatic \\
\hline 11 & Chenab Basmati & Approved Variety-2016 & Aromatic \\
\hline 12 & Punjab Basmati & Approved Variety-2016 & Aromatic \\
\hline 13 & PK 8892 & Advance uniform line & Aromatic \\
\hline 14 & PK 9194 & Advance uniform line & Aromatic \\
\hline 15 & RRI 3 & Advance uniform line & Aromatic \\
\hline 16 & PKBB 15-1 & Advance uniform line & Aromatic \\
\hline 17 & PKBB 15-6 & Advance uniform line & Aromatic \\
\hline 18 & PKPB 8 & Advance uniform line & Aromatic \\
\hline 19 & PK 10683 & Advance uniform line & Aromatic \\
\hline 20 & PK 10355 & Advance uniform line & Aromatic \\
\hline 21 & PKBB 15-116 & Advance uniform line & Aromatic \\
\hline 22 & PK 10029 & Advance uniform line & Aromatic \\
\hline 23 & PK 9966 & Advance uniform line & Aromatic \\
\hline 24 & PK 9533 & Advance uniform line & Aromatic \\
\hline 25 & PK 10161 & Advance uniform line & Aromatic \\
\hline 26 & PK 10967 & Advance uniform line & Aromatic \\
\hline
\end{tabular}

* These genotypes are maintained at RRI, KSK.

Table 2 Physiochemical characteristics of soil and water samples

\begin{tabular}{|c|c|c|c|}
\hline \multicolumn{2}{|l|}{ Soil characteristics } & \multicolumn{2}{|l|}{ Water characteristics } \\
\hline Sampling Depth (inch) & $0-6$ & Electrical Conductivity $\left(\mathrm{mScm}^{-1}\right)$ & 1.3 \\
\hline Electrical Conductivity $\left(\mathrm{mScm}^{-1}\right)$ & 1.5 & Calcium+Magnesium $\left(\mathrm{Ca}^{2+} \& \mathrm{Mg}^{2+}\right)$ & 5.0 \\
\hline $\mathrm{pH}$ & 8.1 & Sodium $\left(\mathrm{Na}^{+}\right)$ & 6.0 \\
\hline Organic matter $(\%)$ & 0.8 & Carbonate $\left(\mathrm{CO}^{3-)}\right.$ & - \\
\hline Available Phosphorus (mg/kg) & 7.0 & Bi-Carbonate $\left(\mathrm{HCO}^{3-}\right)$ & 5.2 \\
\hline Available Potassium (mg/kg) & 146 & Chloride $\left(\mathrm{Cl}^{-}\right)$ & 2.6 \\
\hline Saturation $(\%)$ & 42 & Residual Sodium Carbonate & 3.2 \\
\hline Texture & Loam & Sodium Absorption Ratio & 4.1 \\
\hline $\mathrm{Fe}(\mathrm{ppm})$ & 12.2 & $\mathrm{Fe}(\mathrm{ppm})$ & 1.12 \\
\hline $\mathrm{Zn}(\mathrm{ppm})$ & 0.87 & $\mathrm{Zn}(\mathrm{ppm})$ & 0.96 \\
\hline
\end{tabular}

Journal of Experimental Biology and Agricultural Sciences 


\subsection{Sample preparation}

Rice panicles were harvested and hand threshed to avoid any metal contamination. For preparation of brown rice, the husk was removed by using a paddy dehusker (Satake, Japan). Brown rice samples were polished with a laboratory polishing machine (Grainman 60M-250-50-DT Sheller, USA) for the same intervals (40 s). The dehusker and polishing machine were thoroughly cleaned after preparation of each sample by brushing the bran and broken rice kernels. For estimation of $\mathrm{Fe}$ and $\mathrm{Zn}$, whole grains were collected, washed with double distilled deionized water $\left(\mathrm{d}_{3} \mathrm{H}_{2} \mathrm{O}\right)$ to remove any metal contamination and oven dried at $70^{\circ}$ $\mathrm{C}$ to bring the moisture level at 10-12 percent.

\subsection{Estimation of Fe and $\mathrm{Zn}$}

Standard procedure was followed for estimation of $\mathrm{Fe}$ and $\mathrm{Zn}$ contents (George et al., 2013). One gram of sample weighed separately for each genotype, transferred quantitatively into 100 $\mathrm{mL}$ pyrex digestion tubes. Ten $\mathrm{mL}$ of di-acid mixture ( $\mathrm{HNO} 3+\mathrm{HClO} 4,2: 1$ ) was added to each tube and allowed to stand overnight until the vigorous reaction phase was over. After preliminary digestion, digestion tubes were placed in a cold-block digester and temperature was raised to $150^{\circ} \mathrm{C}$ for 60 minutes until all traces of $\mathrm{HNO}_{3}$ disappeared. Then, temperature was slowly raised to $235^{\circ} \mathrm{C}$. When white dense fumes of $\mathrm{HClO} 4$ appeared, digestion was continued for 30 more minutes, until white precipitates settled down at the bottom of digestion tubes. $d_{3} \mathrm{H}_{2} \mathrm{O}$ was added in small increments for dissolving the crystals and washing of the tube walls. The contents were filtered through Whatman No. $41 / 42$ filter paper and $50 \mathrm{~mL}$ dilutions were made with $\mathrm{d}_{3} \mathrm{H}_{2} \mathrm{O}$. Finally, extract was fed to atomic absorption spectrophotometer (200 Series AA, Agilent Technologies, USA) available at Soil and Water Testing Laboratory, Thokar Niaz Baig, Lahore for determination of $\mathrm{Fe}$ and $\mathrm{Zn}$ concentration. Each digestion batch contained 11 samples and one blank (no plant material). The analysis was repeated thrice for each genotype and mean value is presented in results. Fe and $\mathrm{Zn}$ concentrations were expressed in parts per million (ppm).

\subsection{Estimation of $\beta$-carotene}

Standard procedure with little modification was followed for estimation of $\beta$-carotene contents (Nagata, 2009). Polished rice grains were grounded using a pestle and mortar. For each genotype, accurately weighed $0.225 \mathrm{~g}$ powder was taken into 15 $\mathrm{mL}$ falcon tubes and $3 \mathrm{~mL}$ of $80 \%$ acetone solution was added to it. After vertexing the mixture for 5 minutes, it was allowed to stand overnight. Next day, the homogenous mixture was centrifuged at 3000 RPM for 5 minutes and supernatant was taken into newly labelled falcon tubes. Finally, the absorbance of extract was measured at $479 \mathrm{~nm}, 645 \mathrm{~nm}$ and $663 \mathrm{~nm}$ wavelengths by using the spectrophotometer $\left(\mathrm{T} 80^{+}\right.$UV/VIS spectrophotometer, PG instruments Ltd., UK). $\beta$-carotene concentration was calculated by putting the absorbance values in following formulae.

Beta carotene $(\mathrm{ppm})=0.854(479 \mathrm{~nm})-0.312(645 \mathrm{~nm})+$ $0.039(663 \mathrm{~nm})-0.005(\mathrm{r}=0.992, \mathrm{SE}=0.0096 \mathrm{ppm})$.

Where,

$r=$ correlation coefficient

$\mathrm{SE}=$ standard error

\subsection{Data analysis}

The one-way analysis of variance and Tukey HSD all pair wise comparison tests were used to compare the mean values of Fe and $\mathrm{Zn}$ contents in both brown and polished rice at probability level of $\alpha \leq 0.05$. Statistical analysis was carried out using the SPSS software (SPSS 16.0, Chicago, USA).

\section{Results}

$\mathrm{Fe}$ and $\mathrm{Zn}$ concentration was analysed in brown and polished grain samples of 26 rice genotypes and significant genetic variation was observed (Table 3). Wide genetic variation in $\mathrm{Fe}$ concentration of brown and polished rice was found as compared to $\mathrm{Zn}$ concentration. Fe concentration in brown rice ranged from $13.23 \mathrm{ppm}$ (PK 10355) to $45.83 \mathrm{ppm}$ (Basmati 370), while in polished rice it ranged from $1.10 \mathrm{ppm}$ (PK 10355) to $36.45 \mathrm{ppm}$ (Basmati 370). Whereas, $\mathrm{Zn}$ concentration in brown rice ranged from 18.67 (PK 10967) ppm to $38.01 \mathrm{ppm}$ (Basmati 370) and in polished rice it ranged from $5.86 \mathrm{ppm}$ (PK 9533) to $23.88 \mathrm{ppm}$ (Kissan Basmati). The mean value for Fe concentration in brown rice was $25.21 \mathrm{ppm}$, whereas in polished rice it was $11.81 \mathrm{ppm}$. Similarly, the mean value for $\mathrm{Zn}$ concentration in brown rice was $23.95 \mathrm{ppm}$, whereas in polished rice it was $12.69 \mathrm{ppm}$ (Table 3). Additionally, large variation in grain Fe contents was due to high availability of this mineral to rice genotypes from the experimental soil (Table 2).

Overall, all approved varieties had high $\mathrm{Fe}$ and $\mathrm{Zn}$ concentration in both brown and polished rice when compared with advance uniform lines. In approved varieties, Fe concentration in brown rice ranged from $16.93 \mathrm{ppm}$ (Chenab Basmati) to $45.83 \mathrm{ppm}$ (Basmati 370), with an average of $27.77 \mathrm{ppm}$. Whereas in advance uniform lines, Fe concentration in brown rice ranged from $13.23 \mathrm{ppm}$ (PK 10355) to $39.32 \mathrm{ppm}$ (PK 8892), with an average of $23.01 \mathrm{ppm}$ (Table 3). Similarly, Zn concentration in brown rice of approved varieties ranged from $19 \mathrm{ppm}$ (Punjab Basmati) to $38.01 \mathrm{ppm}$ (Basmati 370) with an average of 26.76 $\mathrm{ppm}$, however, in advance uniform lines it ranged from $18.67 \mathrm{ppm}$ 
Table $3 \mathrm{Fe}$ and $\mathrm{Zn}$ concentration in 26 rice genotypes

\begin{tabular}{|c|c|c|c|c|}
\hline \multirow{2}{*}{ Genotype } & \multicolumn{2}{|c|}{ Brown Rice } & \multicolumn{2}{|c|}{ Polished Rice } \\
\hline & $\mathrm{Fe}(\mathrm{ppm})$ & $\mathrm{Zn}(\mathrm{ppm})$ & $\mathrm{Fe}(\mathrm{ppm})$ & $\mathrm{Zn}(\mathrm{ppm})$ \\
\hline \multicolumn{5}{|l|}{ Approved Varieties } \\
\hline Basmati 370 & $45.83 \pm 0.0212^{\mathrm{a}}$ & $38.01 \pm 0.0778^{\mathrm{a}}$ & $36.45 \pm 0.0354^{\mathrm{a}}$ & $11.69 \pm 0.0242^{\mathrm{j}}$ \\
\hline Basmati 198 & $36.37 \pm 0.0354^{\mathrm{d}}$ & $33.03 \pm 0.0495^{\mathrm{b}}$ & $18.58 \pm 0.0566^{\mathrm{f}}$ & $18.87 \pm 0.0210^{\mathrm{e}}$ \\
\hline Basmati Pak & $27.80 \pm 0.0221^{\mathrm{f}}$ & $26.71 \pm 0.2051^{\mathrm{c}}$ & $10.80 \pm 0.0145^{\mathrm{k}}$ & $10.39 \pm 0.0230^{\mathrm{n}}$ \\
\hline Basmati 385 & $41.65 \pm 0.0358^{\mathrm{b}}$ & $27.09 \pm 0.0283^{\mathrm{c}}$ & $21.08 \pm 0.0152^{\mathrm{d}}$ & $22.27 \pm 0.0212^{\mathrm{c}}$ \\
\hline Super Basmati & $20.13 \pm 0.0212^{\mathrm{m}}$ & $24.65 \pm 0.0232^{\mathrm{h}}$ & $5.20 \pm 0.0141^{\mathrm{s}}$ & $7.87 \pm 0.0424^{\mathrm{s}}$ \\
\hline Basmati 2000 & $25.10 \pm 0.0360^{\mathrm{h}}$ & $26.29 \pm 0.0424^{\mathrm{d}}$ & $14.35 \pm 0.0210^{\mathrm{i}}$ & $12.53 \pm 0.0778^{\mathrm{i}}$ \\
\hline Basmati 515 & $21.95 \pm 0.0372^{\mathrm{j}}$ & $23.36 \pm 0.0707^{\mathrm{i}}$ & $16.70 \pm 0.0140^{\mathrm{h}}$ & $18.46 \pm 0.0265^{\mathrm{f}}$ \\
\hline PK 386 & $25.17 \pm 0.0283^{\mathrm{h}}$ & $24.98 \pm 0.0141^{\mathrm{g}}$ & $17.73 \pm 0.0228^{g}$ & $19.25 \pm 0.0354^{\mathrm{d}}$ \\
\hline PK 1121 Aromatic & $20.45 \pm 0.0216^{\mathrm{lm}}$ & $26.78 \pm 0.0283^{\mathrm{c}}$ & $11.65 \pm 0.0360^{\mathrm{j}}$ & $9.52 \pm 0.0141^{\circ}$ \\
\hline Kissan Basmati & $30.75 \pm 0.0358^{\mathrm{e}}$ & $26.51 \pm 0.0512^{\mathrm{d}}$ & $24.75 \pm 0.0212^{\mathrm{c}}$ & $23.88 \pm 0.0157^{\mathrm{a}}$ \\
\hline Chenab Basmati & $16.93 \pm 0.0141^{\mathrm{p}}$ & $24.72 \pm 0.0566^{\mathrm{gh}}$ & $4.55 \pm 0.0200^{\mathrm{t}}$ & $12.54 \pm 0.0283^{\mathrm{i}}$ \\
\hline Punjab Basmati & $21.15 \pm 0.0849^{\mathrm{k}}$ & $19.00 \pm 0.0861^{\circ}$ & $7.55 \pm 0.0145^{\circ}$ & $8.94 \pm 0.0354^{\mathrm{q}}$ \\
\hline Mean & 27.77 & 26.76 & 15.78 & 14.68 \\
\hline Minimum & 16.93 & 19.00 & 4.55 & 7.87 \\
\hline Maximum & 45.83 & 38.01 & 36.45 & 23.88 \\
\hline \multicolumn{5}{|c|}{ Advance Uniform Lines } \\
\hline PK 8892 & $39.32 \pm 0.4808^{\mathrm{c}}$ & $26.37 \pm 0.0217^{\mathrm{d}}$ & $26.40 \pm 0.0150^{\mathrm{b}}$ & $23.24 \pm 0.0424^{\mathrm{b}}$ \\
\hline PK 9194 & $28.07 \pm 0.0495^{\mathrm{f}}$ & $19.55 \pm 0.0390^{\mathrm{n}}$ & $5.68 \pm 0.0141^{\mathrm{q}}$ & $11.31 \pm 0.0293^{\mathrm{k}}$ \\
\hline RRI 3 & $22.98 \pm 0.0566^{\mathrm{i}}$ & $19.18 \pm 0.0636^{\circ}$ & $10.63 \pm 0.0210^{1}$ & $10.82 \pm 0.0181^{\mathrm{m}}$ \\
\hline PKBB 15-1 & $25.23 \pm 0.0212^{\mathrm{h}}$ & $25.27 \pm 0.0778^{\mathrm{f}}$ & $7.95 \pm 0.0919^{\mathrm{n}}$ & $8.68 \pm 0.0768^{\mathrm{r}}$ \\
\hline PKBB 15-6 & $27.15 \pm 0.0354^{\mathrm{g}}$ & $21.92 \pm 0.0560^{\mathrm{k}}$ & $5.50 \pm 0.0225^{\mathrm{r}}$ & $10.44 \pm 0.0432^{\mathrm{n}}$ \\
\hline PKPB 8 & $25.33 \pm 0.0919^{\mathrm{h}}$ & $21.77 \pm 0.0200^{\mathrm{k}}$ & $6.70 \pm 0.0636^{\mathrm{p}}$ & $10.35 \pm 0.0438^{n}$ \\
\hline PK 10683 & $20.85 \pm 0.0360^{\mathrm{kl}}$ & $19.96 \pm 0.0283^{\mathrm{m}}$ & $10.30 \pm 0.0424^{\mathrm{m}}$ & $9.37 \pm 0.0490^{\mathrm{p}}$ \\
\hline PK 10355 & $13.23 \pm 0.0210^{\mathrm{r}}$ & $20.50 \pm 0.1556^{1}$ & $1.10 \pm 0.0653^{\mathrm{w}}$ & $13.56 \pm 0.0220^{\mathrm{h}}$ \\
\hline PKBB 15-116 & $19.67 \pm 0.1202^{\mathrm{n}}$ & $25.90 \pm 0.0707^{\mathrm{e}}$ & $3.00 \pm 0.0168^{\mathrm{u}}$ & $16.54 \pm 0.0238^{\mathrm{g}}$ \\
\hline PK 10029 & $17.97 \pm 0.0283^{\circ}$ & $22.59 \pm 0.0350^{\mathrm{j}}$ & $7.90 \pm 0.0707^{\mathrm{n}}$ & $10.88 \pm 0.0849^{1}$ \\
\hline PK 9966 & $15.02 \pm 0.0570^{\mathrm{q}}$ & $19.98 \pm 0.0428^{\mathrm{m}}$ & $4.50 \pm 0.0140^{\mathrm{t}}$ & $7.81 \pm 0.0636^{\mathrm{s}}$ \\
\hline PK 9533 & $22.93 \pm 0.0424^{\mathrm{i}}$ & $20.03 \pm 0.0420^{\mathrm{m}}$ & $20.80 \pm 0.1414^{\mathrm{e}}$ & $5.86 \pm 0.0280^{\mathrm{u}}$ \\
\hline PK 10161 & $22.63 \pm 0.0241^{\mathrm{i}}$ & $20.01 \pm 0.0454^{\mathrm{m}}$ & $1.71 \pm 0.0156^{\mathrm{v}}$ & $6.06 \pm 0.0283^{\mathrm{t}}$ \\
\hline PK 10967 & $21.73 \pm 0.0374^{\mathrm{j}}$ & $18.67 \pm 0.0283^{\mathrm{p}}$ & $5.45 \pm 0.0354^{\mathrm{r}}$ & $8.95 \pm 0.0345^{\mathrm{q}}$ \\
\hline Mean & 23.01 & 21.55 & 8.40 & 10.99 \\
\hline Minimum & 13.23 & 18.67 & 1.10 & 5.86 \\
\hline Maximum & 39.32 & 26.37 & 26.40 & 23.24 \\
\hline $\begin{array}{l}\text { Coefficient of } \\
\text { variation }(\%)\end{array}$ & 31.65 & 18.88 & 73.95 & 41.29 \\
\hline Overall Mean & 25.21 & 23.95 & 11.81 & 12.69 \\
\hline Overall Minimum & 13.23 & 18.67 & 1.10 & 5.86 \\
\hline Overall Maximum & 45.83 & 38.01 & 36.45 & 23.88 \\
\hline Standard Deviation & 7.97 & 4.52 & 8.73 & 5.24 \\
\hline
\end{tabular}

Mean \pm standard deviation. Values sharing same alphabets in columns differ non-significantly ( $\mathrm{P}>0.05)$. 
(PK 10967) to $26.37 \mathrm{ppm}$ (PK 8892) with an average of 21.55 ppm. Similar Fe and $\mathrm{Zn}$ acquisition patterns were also observed in polished rice, where concentration of $\mathrm{Fe}$ in approved varieties ranged from $4.55 \mathrm{ppm}$ (Chenab Basmati) to $36.45 \mathrm{ppm}$ (Basmati 370) with an average of $15.78 \mathrm{ppm}$, however, in advance uniform lines it ranged from $1.10 \mathrm{ppm}$ ( $\mathrm{PK}$ 10355) to $26.40 \mathrm{ppm}$ (PK 8892 ) with an average of $8.40 \mathrm{ppm}$. Likewise, concentration of $\mathrm{Zn}$ in approved varieties ranged from $7.87 \mathrm{ppm}$ (Super Basmati) to $23.88 \mathrm{ppm}$ (Kissan Basmati) with an average of $14.68 \mathrm{ppm}$, whereas in advance uniform lines it ranged from $5.86 \mathrm{ppm}(\mathrm{PK}$ 9533) to $23.24 \mathrm{ppm}$ (PK 8892) with an average of $10.99 \mathrm{ppm}$ (Table 3).

$\mathrm{Fe}$ and $\mathrm{Zn}$ contents were decreasing in rice grains with the passage of time. Among all approved varieties, 7 varieties had high Fe density (>25 ppm) in brown rice (Basmati 370, Basmati 198, Basmati Pak, Basmati 385, Basmati 2000, PK 386 and Kissan Basmati) and almost all of these varieties also contained high $\mathrm{Zn}$ density (>25 ppm) (Figure 1). However, only 5 advance uniform lines showed high Fe density in brown rice (PK 8892, PK 9194, PKBB 15-1, PKBB 15-6 and PKPB 8) and just 2 out of total 5 high Fe density advance uniform lines also contained high Zn density. Furthermore, 3 approved varieties (Basmati 370, Basmati 385 and Kissan Basmati) and only 2 advance uniform lines (PK 8892 and PK 9533) contained high Fe density in white rice (>20 ppm). Similarly, 2 approved varieties (Basmati 385 and Kissan Basmati) and only one advance uniform line (PK 8892) contained high $\mathrm{Zn}$ density in white rice (>20 ppm) (Table 3).

Significant positive correlations were observed between these two mineral elements and possibility for simultaneous improvement. Grain $\mathrm{Fe}$ and $\mathrm{Zn}$ were strongly correlated in brown rice $(\mathrm{r}=0.694$, $\mathrm{P}<0.01)$ and polished rice $(\mathrm{r}=0.533, \mathrm{P}<0.01)$. High Fe genotypes $(>25 \mathrm{ppm})$ also contained high $\mathrm{Zn}(>25 \mathrm{ppm})$ and vice versa (Figure 1). Among 12 high Fe genotypes, 9 genotypes contained high $\mathrm{Zn}$ contents in brown rice. Similarly, 9 genotypes, out of total 10 high $\mathrm{Zn}$ genotypes also contained high $\mathrm{Fe}$ in brown rice.

Polishing process greatly reduced the $\mathrm{Fe}$ and $\mathrm{Zn}$ concentration in polished rice. Loss in $\mathrm{Fe}$ concentration was greater than $\mathrm{Zn}$ concentration. In approved varieties, less reduction in $\mathrm{Fe}$ and $\mathrm{Zn}$ concentration was observed as compared with advance uniform lines (Figure 2). Among approved varieties, maximum Fe was lost in Super Basmati $(74.17 \%)$ and minimum in Kissan Basmati (19.51\%), whereas maximum $\mathrm{Zn}$ was lost in Basmati 370 $(69.26 \%)$ and minimum in Kissan Basmati (9.92\%). Among advance uniform lines, maximum $\mathrm{Fe}$ was lost in PK 10161 (92.43\%) and minimum in PK 9533 (9.30\%), whereas maximum Zn was lost in PK 9533 (70.72\%) and minimum in PK 8892 (11.86\%). Overall, four genotypes (Kissan Basmati, Basmati 515, PK 386 and PK 8892) were found to be least affected by the polishing process and lost minimum $\mathrm{Fe}$ and $\mathrm{Zn}$ contents (Figure 2). We also found significant positive correlations in $\mathrm{Fe}(\mathrm{r}=0.800$, $\mathrm{P}<0.01)$ and $\mathrm{Zn}$ concentration $(\mathrm{r}=0.440, \mathrm{P}<0.05)$ between polished rice and brown rice.

Narrow genetic variability was present among studied rice genotypes for $\beta$-carotene concentration that ranged from 0.000 (Basmati 198, PK 10029) to 0.055 ppm (PK 8892), with an average of $0.012 \mathrm{ppm}$ (Figure 3). Only 4 genotypes, including 2
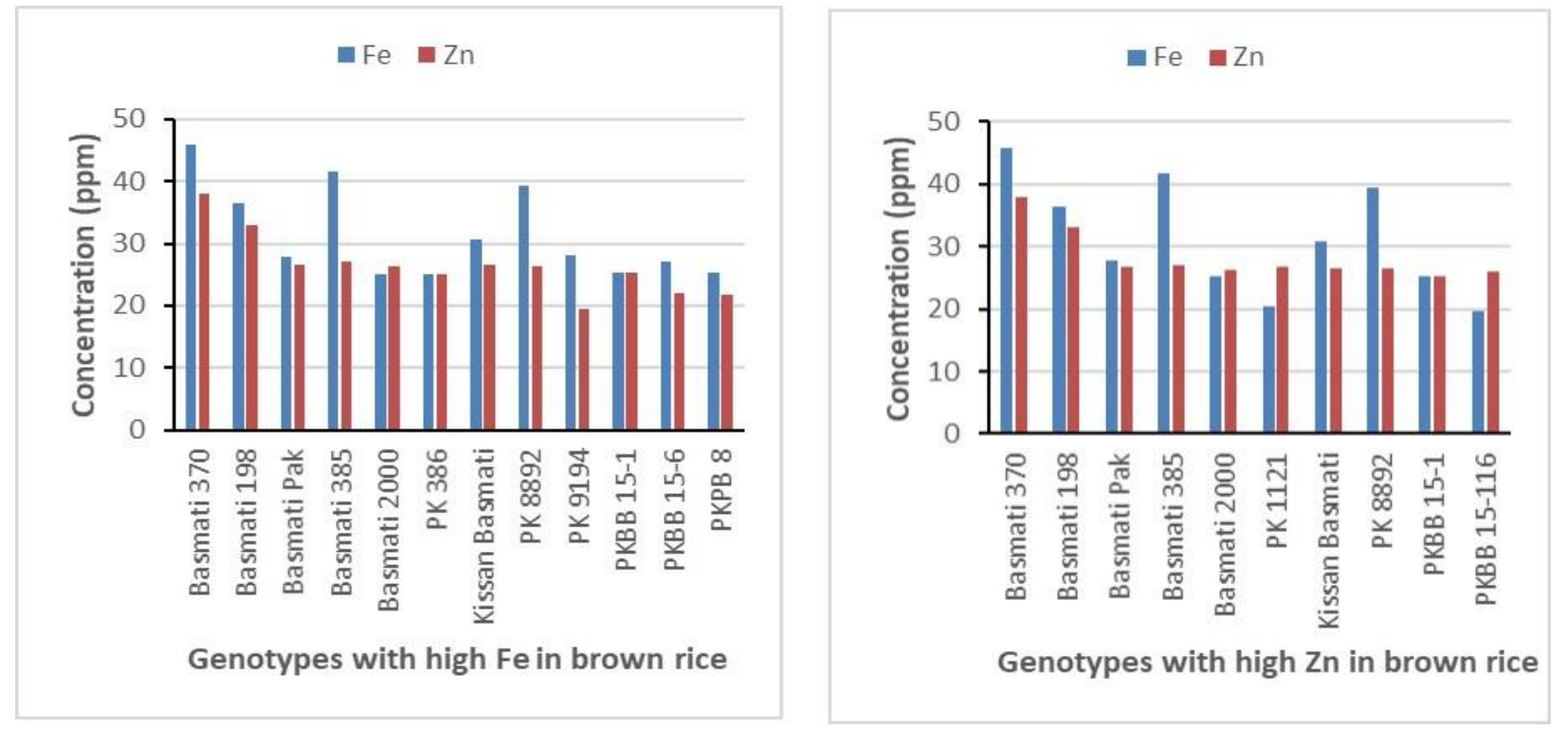

Figure 1 Concentration of $\mathrm{Fe}$ and $\mathrm{Zn}$ in genotypes containing $\geq 25 \mathrm{ppm} \mathrm{Fe}$ or $\mathrm{Zn}$ in brown rice.

Journal of Experimental Biology and Agricultural Sciences http://www.jebas.org 


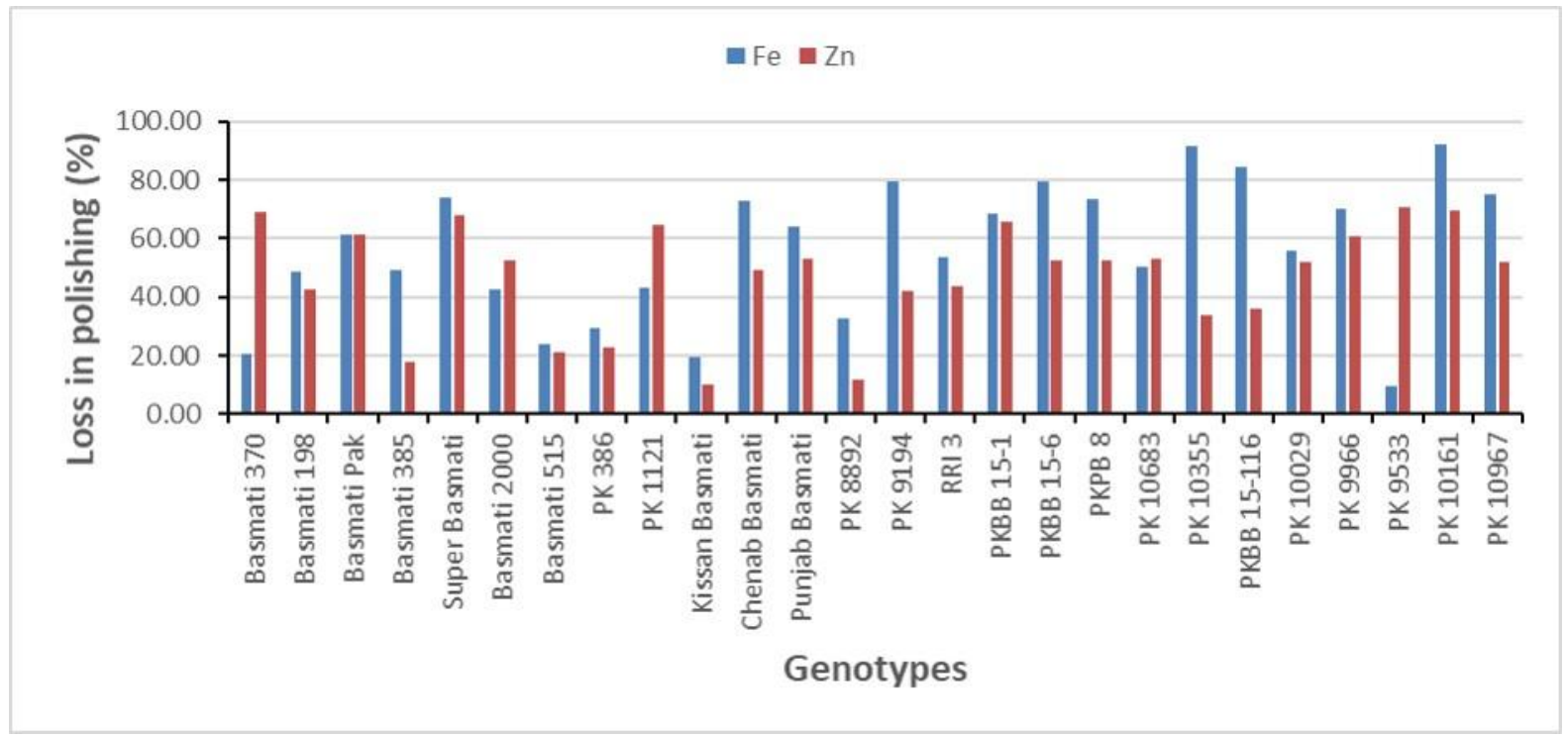

Figure 2 Effect of polishing on Fe and $\mathrm{Zn}$ concentration of all traditional rice genotypes

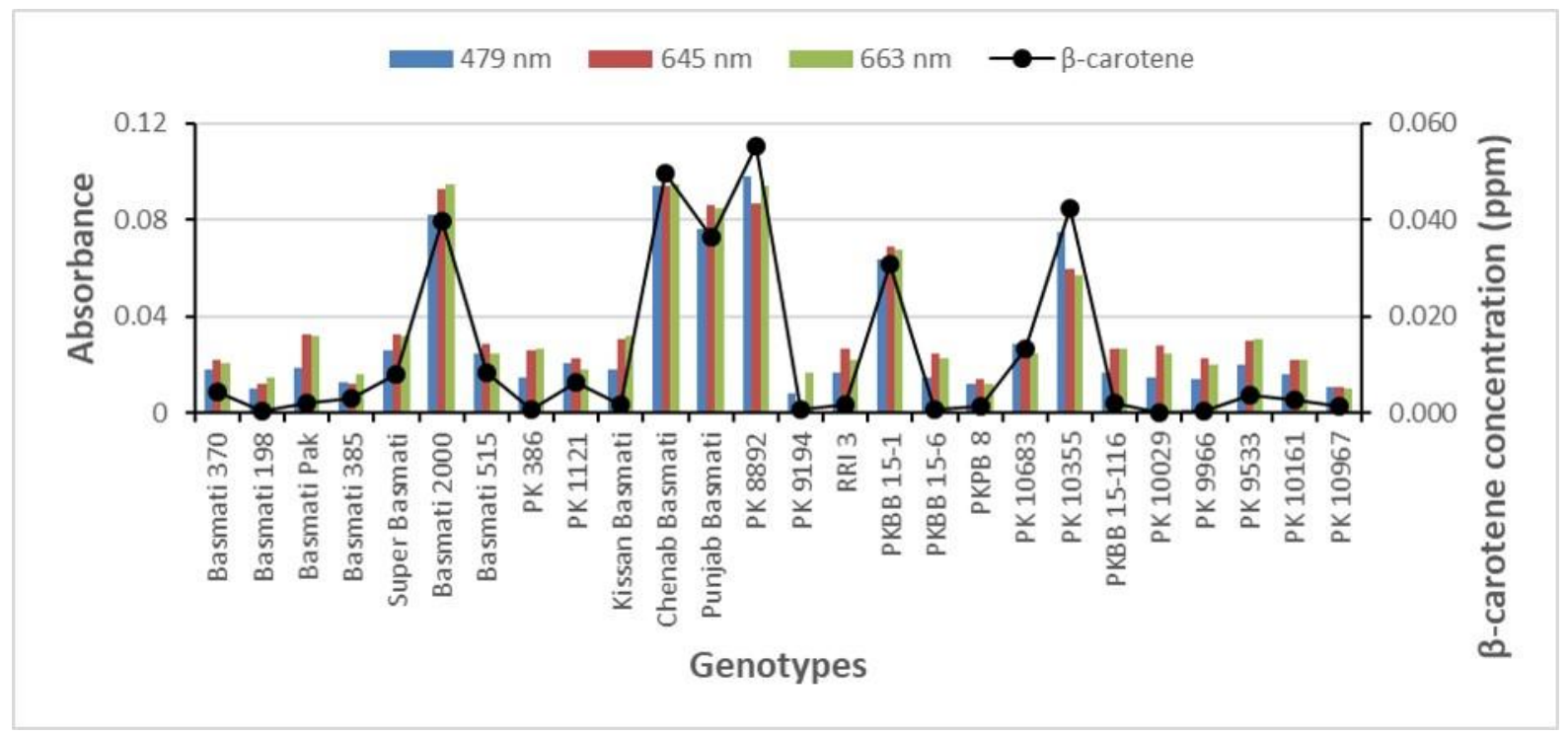

Figure $3 \beta$-carotene concentration levels detected in all traditional rice genotypes

approved varieties (Basmati 2000, Chenab Basmati) and 2 advance uniform lines (PK 8892, PK 10355), contained $\geq 0.040$ $\mathrm{ppm} \beta$-carotene in polished rice indicating need for genetic modification of the rice plant so that the grain accumulates higher concentration of $\beta$-carotene.

\section{Discussions and Conclusion}

Biofortification is a process of increasing the concentration of essential micronutrients and vitamins in a crop plant through agronomic practices, plant breeding or transgenic techniques. Exploring the available genetic diversity for $\mathrm{Fe}, \mathrm{Zn}$ and provitamin A in edible parts of the crop plants is a first step towards developing the nutrient dense biofortified crops (Bouis \& Saltzman, 2017). The objectives of this screening are to identify the donor parents for initiating the breeding programs and existing varieties or pre-varieties in the release pipeline for "fast-tracking." Fast-tracking refers to commercializing the genotypes that combine the desired micronutrient concentration without compromising farmer preferred agronomic traits so they can be 
released without delay. Increasing $\mathrm{Fe}, \mathrm{Zn}$ and pro-vitamin $\mathrm{A}$ density in cereal grains is a high priority research area. Exploration and exploitation of available genetic diversity in cereal germplasm for $\mathrm{Fe}, \mathrm{Zn}$ and pro-vitamin $\mathrm{A}$ is a basic approach for alleviating the malnutrition of billions worldwide.

In rice, large genetic variation has been reported for grain $\mathrm{Fe}$ and Zn concentration (Cai et al., 2009; Banerjee et al., 2010; Anandan et al., 2011; Brar et al., 2011; Anuradha et al., 2012; Roy \& Sharma, 2014; Patil et al., 2015; Umadevi et al., 2016). In this study, 26 rice genotypes including approved varieties and advance uniform lines were screened for $\mathrm{Fe}, \mathrm{Zn}$ and $\beta$-carotene contents in rice grains. Significant genetic variation was present in brown rice, as well as in white rice, for Fe and $\mathrm{Zn}$ concentration (Table 3 ), thus holding promise for further trait improvement. Among screened genotypes, those which were released until 2000 (the landraces), contained high $\mathrm{Fe}$ and $\mathrm{Zn}$ densities (>25 ppm) in brown rice, except Super Basmati. However, those genotypes which were released after 2000 or are in release pipeline, contained lower $\mathrm{Fe}$ and $\mathrm{Zn}$ densities in brown rice ( $<25 \mathrm{ppm})$, except Kissan Basmti, PK 8892 and PKBB 15-1 (Table 3). These data indicate that landraces contains higher $\mathrm{Fe}$ and $\mathrm{Zn}$ densities in their grains and may be used as donor parents in future rice breeding programs. Previously, maximum $\mathrm{Fe}$ and $\mathrm{Zn}$ densities have been reported in some landraces and /or distantly related wild species (Anandan et al., 2011; Brar et al., 2011; Anuradha et al., 2012; Roy \& Sharma, 2014; Patil et al., 2015; Umadevi et al., 2016), which support the consistency and accuracy of our data.

In previous studies, strong positive association between grain $\mathrm{Fe}$ and $\mathrm{Zn}$ concentration has been reported (Baxter et al., 2013; Moreno-Moyano et al., 2016). In this study, we also found strong positive association between grain $\mathrm{Fe}$ and $\mathrm{Zn}$ concentration in brown rice $(\mathrm{r}=0.694, \mathrm{P}<0.01)$, as well as, in polished rice $(\mathrm{r}=$ $0.533, \mathrm{P}<0.01)$. Furthermore, high Fe varieties $(>25 \mathrm{ppm})$ also had high $\mathrm{Zn}(>25 \mathrm{ppm}$ ) and vice versa (Figure 1). This inherent association between these two mineral elements suggest presence of linkage between micronutrient accumulation genes or pleotropic effects of these genes. Majority of the genes encode metal transporter proteins and some of which transport multiple metals (Qin et al., 2012). Thus, grain Fe and $\mathrm{Zn}$ can be improved simultaneously.

Rice is mainly consumed worldwide as polished rice. The polishing process is performed to improve the physical and sensory attributes, as well as to increase the storage stability of rice (Monks et al., 2013). However, polishing process diminishes the overall nutritional value by removing the bran layers and germ which are rich source of minerals, proteins, vitamins, fibers and fats (Paiva et al., 2016). In this study, Fe and $\mathrm{Zn}$ concentration was greatly reduced by the polishing process. However, loss in Fe concentration was greater than $\mathrm{Zn}$ concentration. Moreover, advance uniform lines lost more $\mathrm{Fe}$ and $\mathrm{Zn}$ contents as compared to approved varieties (Figure 2). These unequal losses in $\mathrm{Fe}$ and $\mathrm{Zn}$ might arise due to high concentration of $\mathrm{Fe}$, but not $\mathrm{Zn}$, in experimental soil (Table 2). We also found significant positive correlations in $\mathrm{Fe}(\mathrm{r}=0.800, \mathrm{P}<0.01)$ and $\mathrm{Zn}$ concentration $(\mathrm{r}=$ $0.440, \mathrm{P}<0.05$ ) between polished rice and brown rice. Wei et al. (2012) investigated the effects of foliar iron applications on Fe and $\mathrm{Zn}$ concentration in polished rice and demonstrated that concentration of $\mathrm{Fe}$, but not $\mathrm{Zn}$, was greatly reduced in polished rice. They also found significant positive correlation in $\mathrm{Fe}$ concentration between polished rice and brown rice. Their findings are consistent with our results and indicate predominant deposition of $\mathrm{Fe}$ and $\mathrm{Zn}$ in bran layers and endosperm, respectively.

In Asia, vitamin A deficiency is associated with the poverty related predominant consumption of rice, which lacks pro-vitamin $A$ in endosperm (Paine et al., 2005). Minimal levels of $\beta$-carotene are reported in rice endosperm (Beyer, 2010) and wheat (Badakhshan et al., 2013). In this study, we also found narrow genetic diversity among rice genotypes for $\beta$-carotene contents in endosperm (Figure 3), suggesting use of transgenic techniques rather than conventional breeding efforts for increasing the provitamin A concentration in rice endosperm.

In conclusion, wide genetic diversity exists in rice for grain $\mathrm{Fe}$ and $\mathrm{Zn}$ concentration and narrow genetic diversity for $\beta$-carotene concentration. Landraces contain higher $\mathrm{Fe}$ and $\mathrm{Zn}$ concentration in their grains and are less affected by the polishing process, thus, can be good sources of high $\mathrm{Fe}$ and $\mathrm{Zn}$ in future nutrition breeding programs. Strong inherent associations between $\mathrm{Fe}$ and $\mathrm{Zn}$ in brown rice and polished rice provide opportunity for simultaneous improvement of both microelements.

\section{Acknowledgment}

This study was financially supported by the Punjab Agricultural Research Board (PARB) CGS project no. 904 titled 'Nutrition enhancement of crops, fruits, vegetables and their products under climate change scenario.'

\section{Conflict of interest}

All the authors declare that there is no conflict of interest.

\section{References}

Anandan A, Rajiv G, Eswaran R, Prakash M (2011) Genotypic variation and relationships between quality traits and trace elements in traditional and improved rice (Oryza sativa L.) genotypes. Journal of food science, 76: H122-H130.

Anuradha K, Agarwal S, Batchu AK, Babu AP, Swamy BM, Longvah T, Sarla N (2012) Evaluating rice germplasm for iron 
and zinc concentration in brown rice and seed dimensions. Journal of Phytology 4: 19-25.

Badakhshan H, Moradi N, Mohammadzadeh H, Zakeri MR (2013) Genetic variability analysis of grains $\mathrm{Fe}, \mathrm{Zn}$ and betacarotene concentration of prevalent wheat varieties in Iran. International Journal of Agriculture and Crop Sciences 6: 57-62.

Banerjee S, Sharma D, Verulkar S, Chandel G (2010) Use of in silico and semiquantitative RT-PCR approaches to develop nutrient rich rice (Oryza sativa L.). Indian Journal of Biotechnology 9: 203-212.

Baxter IR, Gustin JL, Settles AM, Hoekenga OA (2013) Ionomic characterization of maize kernels in the intermated B73× Mo17 population. Crop Science 53: 208-220.

Beyer P (2010) Golden Rice and 'Golden'crops for human nutrition. New Biotechnology 27: 478-481.

Black R (2003) Micronutrient deficiency: an underlying cause of morbidity and mortality. SciELO Public Health.

Bouis HE, Hotz C, McClafferty B, Meenakshi J, Pfeiffer WH (2011) Biofortification: a new tool to reduce micronutrient malnutrition. Food and nutrition bulletin 32: S31-S40.

Bouis HE, Saltzman A (2017) Improving nutrition through biofortification: a review of evidence from HarvestPlus, 2003 through 2016. Global Food Security 12: 49-58.

Brar B, Jain S, Singh R, Jain R (2011) Genetic diversity for iron and zinc contents in a collection of 220 rice (Oryza sativa L.) genotypes. Indian Journal of Genetics and Plant Breeding71: 67-73.

Brotanek JM, Halterman JS, Auinger P, Flores G, Weitzman M (2005) Iron deficiency, prolonged bottle-feeding, and racial/ethnic disparities in young children. Archives of Pediatrics \& Adolescent Medicine 159: 1038-1042.

Cai JC, Cao JI, Shu AP, Jin ZQ, Han LZ (2009) Difference of iron contents in rice landraces. Journal of Plant Genetic Resources 1: 0-12.

Dalmiya N, Palmer A (2007) Vitamin A supplementation: A decade of progress. UNICEF.

George E, Rolf S, John R (2013) Methods of Soil, Plant, and Water Analysis. A Manual for the West Asia and North Africa region. International Center for Agricultural Research in the Dry Areas (ICARDA).

Maret W, Sandstead HH (2006) Zinc requirements and the risks and benefits of zinc supplementation. Journal of Trace Elements in Medicine and Biology 20: 3-18.
Meenakshi JV, Johnson N, Manyong V, Groote D, Javelosa H, Yanggen JD, Naher F (2010) How cost-effective is biofortification in combating micronutrient malnutrition? An exante assessment. World Development 38: 64-75.

Meng F, Wei Y, Yang X (2005) Iron content and bioavailability in rice. Journal of Trace Elements in Medicine and Biology 18: 333-338.

McGuire S, FAO, IFAD, WFP (2015) The state of food insecurity in the world 2015: meeting the 2015 international hunger targets: taking stock of uneven progress. Rome: FAO, Oxford University Press.

Monks JLF, Vanier NL, Casaril J, Berto RM, de Oliveira M, Gomes CB, de Carvalho MP, Dias ARG, Elias MC (2013) Effects of milling on proximate composition, folic acid, fatty acids and technological properties of rice. Journal of Food Composition and Analysis 30: 73-79.

Moreno-Moyano LT, Bonneau JP, Sánchez-Palacios JT, Tohme J, Johnson AA (2016) Association of increased grain iron and zinc concentrations with agro-morphological traits of biofortified rice. Frontiers in plant science 30: 73-79.

Nagata MA (2009) Simple spectrophotometric method for the estimation of $\beta$-carotene content in spinach acetone extracts. Bulletin of the National Institute of Vegetable and Tea Science 8: 1-5.

Paine JA, Shipton CA, Chaggar S, Howells RM, Kennedy MJ, Vernon G, Wright SY, Hinchliffe E, Adams JL, Silverstone AL (2005) Improving the nutritional value of Golden Rice through increased pro-vitamin A content. Nature Biotechnology 23: 482-487.

Paiva FF, Vanier NL, Berrios JDJ, Pinto VZ, Wood D, Williams T, Pan J, Elias MC (2016) Polishing and parboiling effect on the nutritional and technological properties of pigmented rice. Food chemistry 191: 105-112.

Patil R, Diwan J, Nidagundi J, Lokesha R, Ravi M, Boranayak M, Dikshith S (2015) Genetic diversity of brown rice for iron and zinc content. Electronic Journal of Plant Breeding 6: 196-203.

Qin H, Cai Y, Liu Z, Wang G, Wang J, Guo Y, Wang H (2012) Identification of QTL for zinc and iron concentration in maize kernel and cob. Euphytica 187: 345-358.

Roy SC, Sharma B (2014) Assessment of genetic diversity in rice [Oryza sativa L.] germplasm based on agro-morphology traits and zinc-iron content for crop improvement. Physiology and Molecular Biology of Plants 20: 209-224.

Stevens GA, Finucane MM, De-Regil LM, Paciorek CJ, Flaxman SR, Branca F, Peña-Rosas JP, Bhutta ZA, Ezzati M, Group NIMS (2013) Global, regional, and national trends in haemoglobin concentration and prevalence of total and severe anaemia in 
children and pregnant and non-pregnant women for 1995-2011: a systematic analysis of population-representative data. The Lancet Global Health 1: e16-e25.

Umadevi M, Saraswathi R, Shanthi P, Suresh R, Rao D, Rajendran R (2016) Assessment of genetic variability in traditional rice varieties based on agro-morphological traits and iron zinc content for crop improvement. International Journal of Science and Nature 7: 244-250.

Wei Y, Shohag MJI, Yang X, Yibin Z (2012) Effects of Foliar Iron Application on Iron Concentration in Polished Rice Grain and Its Bioavailability. Journal of Agricultural and Food Chemistry 60:11433-11439.

WHO (2009) Global prevalence of vitamin A deficiency in populations at risk 1995-2005. Available at http://apps.who.int/iris/bitstream/10665/44110/1/9789241598019_ eng.pdf?ua=1 accessed on 15 January 2019.

WHO (2015) Malnutrition. Available at: https://www.who.int /news-room/factsheets/detail/malnutrition accessed on 15 January 2019. 